\title{
Analysis of candidate target genes for mononucleotide repeat mutation in microsatellite instability-high (MSI-H) endometrial cancer
}

\author{
MAKIKO KAWAGUCHI, KOUJI BANNO, MEGUMI YANOKURA, YUSUKE KOBAYASHI, \\ ARISA KISHIMI, SEIJI OGAWA, IORI KISU, HIROYUKI NOMURA, \\ AKIRA HIRASAWA, NOBUYUKI SUSUMU and DAISUKE AOKI
}

Department of Obstetrics and Gynecology, Keio University School of Medicine, Tokyo, Japan

Received June 12, 2009; Accepted August 4, 2009

DOI: 10.3892/ijo_00000411

\begin{abstract}
Microsatellite instability (MSI) is an indicator of DNA instability and is caused by abnormalities in DNA mismatch repair (MMR) genes such as $h M L H 1, h M S H 2$ and $h M S H 6$. MSI occurs frequently in endometrial cancer (in approximately $30 \%$ of cases), and accumulation of gene mutations due to MSI may therefore have a major role in the mechanism of malignant transformation. However, a responsible target gene has not been identified in endometrial cancer. In this study, we analyzed mutations in 11 cancerrelated genes with mononucleotide repeats susceptible to MSI in a coding region [ $h M S H 3$ (A8), $h M S H 6$ (C8), TGF- $\beta R I I$ (A10), MBD4 (A10), BAX (G8), PTEN (A6 in exon 7), HDAC2 (A9), EPHB2 (A9), Caspase-5 (A10), TCF-4 (A9) and Axin2 (G7)] in 22 patients with MSI-H sporadic endometrial cancer. Mutations in hMSH6 (C8) and TGF- $\beta R I I$ (A10) were found most frequently, at rates of $36.3 \%(8 / 22)$ each. Mutations of $B A X(\mathrm{G} 8)$ and $T C F-4$ (A9), which are common in MSI-positive colorectal cancer, occurred at rates of 22.7 and $0 \%$, respectively, which suggests that the MSI target gene may differ between endometrial and colorectal cancers. Mutations in hMSH6 (C8) were correlated with reduced protein expression $(\mathrm{p}=0.042)$ and patients with these mutations had significantly more mutations in mononucleotide repeats in other cancer-related genes compared to patients without hMSH6 (C8) mutations $(\mathrm{p}=0.042)$. This suggests the possibility of a novel cascade in carcinogenesis of endometrial cancer in which MSI mutates hMSH6 (C8), increases gene instability, and leads to accumulation of mutations in other cancer-related genes. To our knowledge, this is the first report to show that hMSH6 (C8) has an important role as an MSI target gene in sporadic endometrial cancer.
\end{abstract}

Correspondence to: Dr Kouji Banno, Department of Obstetrics and Gynecology, Keio University School of Medicine, Shinanomachi 35, Shinjuku-ku, Tokyo 160-8582, Japan

E-mail: kbanno@sc.itc.keio.ac.jp

Key words: endometrial cancer, microsatellite instability, $h M S H 6$, mutation, mononucleotide repeat

\section{Introduction}

Microsatellite instability (MSI) is an indicator of genetic instability at the DNA level $(1,2)$. MSI can be evaluated by PCR-based detection of errors in replication of DNA sequences called microsatellites, which consist of repeating units of 1-2 base pairs. MSI has been found in many carcinomas and is particularly common in patients with hereditary non-polyposis colorectal cancer (HNPCC), a familial colon and endometrial cancer that is frequently MSI-positive (3). The mutated genes associated with HNPCC, $h M L H 1(4,5), h M S H 2(6,7), h M S H 3$ (8), hMSH6 $(9,10), h P M S 1$ and $h P M S 2$ (11), are mismatch repair (MMR) genes that repair errors during DNA replication. In HNPCC patients, germline mutations in these genes cause abnormalities in the MMR system, which results in frequent errors in target genes. In addition, approximately $15 \%$ of patients with non-hereditary sporadic colon cancer are MSIpositive (3). This may be due to inactivation of the $h M L H 1$ gene promoter by aberrant hypermethylation, which causes abnormalities in the MMR system similar to that in HNPCC and results in unstable MSI-positive genes $(12,13)$. About $30 \%$ of patients with sporadic endometrial cancer are also MSIpositive $(14,15)$ and this may also be due to inactivation of hypermethylated $h M L H l(16)$.

In somatic cells, replication errors are likely to occur in DNA regions including repeat sequences. MSI-based mutations accumulate in target genes with repeat sequences, resulting in malignant transformation of cells. In particular, mutation of tumor suppressor genes with a mononucleotide or dinucleotide repeats (repeating unit of one or two base pairs, respectively) may be strongly associated with malignant transformation of cells. Cancer-related genes including mononucleotide repeats (i.e., candidate MSI-target genes) include TGF- $\beta R$ II (17) and PTEN (18), which are related to cell growth inhibition; apoptosis-related BAX (19) and Caspase-5 (20); TCF-4 (21), EPHB2 (22) and AXIN2 (23), which are components of the Wnt-signaling pathway; and HDAC2 (24), which codes for a histone deacetylase. $h M S H 3$ (25) and $h M S H 6$ (26), which are MMR genes, and MBD4 (27), which codes for the methylCpG binding protein, also have a mononucleotide repeat sequence and are also candidate MSI-target genes. In MSIpositive sporadic colorectal cancer, mutations of TGF- $\beta R I I$ (A10) and $B A X$ (G8) have been found in $90 \%$ (28) and $45 \%$ 
Table I. Primer sequences used in gene mutation analysis.

\begin{tabular}{llll}
\hline Gene & Repeat & \multicolumn{1}{c}{ Sense } & \multicolumn{1}{c}{ Antisense } \\
\hline$h M S H 3$ & A8 & AGATGTGAATCCCCTAATCAAGC & ACTCCCACAATGCCAATAAAAAT \\
$h M S H 6$ & C8 & GGGTGATGGTCCTATGTGTC & CGTAATGCAAGGATGGCGT \\
$T G F-\beta R I I$ & A10 & CTTTATTCTGAAGATGCTGC & GAAGAAAGTCTCACCAGG \\
$M B D 4$ & A10 & TGACCAGTGAAGAAAACAGCC & GTTTATGATGCCAGAAGTTTTTG \\
$B A X$ & G8 & ATCCAGGATCGAGCAGGGCG & ACTCGCTCAGCTTCTTGGTG \\
$P T E N$ & A6 & CCTGTGAAATAATACTGGTATG & CTCCCAATGAAAGTAAAGTACA \\
$H D A C 2$ & A9 & ACCTCCGATTCCGAGCTTT & CCGCTCACCGTCGTAGTAGT \\
EPHB2 & A9 & CACGAGACGTCACCAAGAAA & CGCAAGAACAGTCATTGCTTT \\
Caspase-5 & A10 & CAGAGTTATGTCTTAGGTGAAGG & ACCATGAAGAACATCTTTGCCAG \\
$T C F-4$ & A9 & GCCTCTATTCACAGATAACTC & GTTCACCTTGTATGTAGCGAA \\
Axin 2 & G7 & CCTACCCCTTGGAGTCTGC & CAGGGTCCTGGGTGAACA \\
\hline
\end{tabular}

(29) of cases, respectively, which suggests that MSI plays an important role in malignant transformation in this cancer. However, the mutation frequency of target genes varies between carcinoma types and a responsible MSI-target gene has not been identified in endometrial cancer. Mutation of the tumor suppressor gene PTEN has been found in MSI-positive endometrial cancer (18). However, genes including mononucleotide repeats have not been investigated in endometrial cancer.

In this study, we analyzed mutations of 11 cancer-related genes with mononucleotide repeat sequences [hMSH3 (A8), hMSH6 (C8), TGF- $\beta R I I$ (A10), MBD4 (A10), BAX (G8), PTEN (A6 in exon 7), HDAC2 (A9), EPHB2 (A9), Caspase-5 (A10), TCF-4 (A9) and Axin2 (G7)] in MSI-positive sporadic endometrial cancer, in order to identify MSI-target genes that contribute to the pathogenic mechanism of endometrial cancer.

\section{Materials and methods}

Clinical specimens. The subjects were 69 patients with endometrial cancer $(\mathrm{G} 1,32 ; \mathrm{G} 2,17$ and G3, 20) who gave informed consent to collection of tissue specimens. Of these patients, 59 had endometrioid adenocarcinoma and 10 had adenosquamous carcinoma. The grade of histological differentiation (G1-G3) and the cancer stage at surgery were determined based on the Guidelines for Endometrial Cancer published by the Japan Society of Obstetrics and Gynecology.

Microsatellite instability (MSI) analysis. Genomic DNA was extracted from normal and tumor tissue samples collected from the 69 patients with endometrial cancer using a Get Pure DNA kit (Dojindo Molecular Technologies, Inc., Kumamoto, Japan). The genomic DNA was PCR amplified at the microsatellite repeat loci D2S123, D5S346, D17S250, BAT26 and BAT25. PCR reactions were performed in a total volume of $25 \mu \mathrm{l}$ containing $10 \mathrm{X}$ buffer, $0.125 \mathrm{mM}$ deoxynucleoside triphosphate, $0.2 \mu \mathrm{M}$ of each primer and 0.25 Units of TaqDNA polymerase. The PCR conditions were as follows: $94^{\circ} \mathrm{C}$ for $10 \mathrm{~min} ; 30$ cycles at $94^{\circ} \mathrm{C}$ for $45 \mathrm{sec}, 58^{\circ} \mathrm{C}$ for $45 \mathrm{sec}$, and $72^{\circ} \mathrm{C}$ for $40 \mathrm{sec}$; followed by a final extension step at $72^{\circ} \mathrm{C}$ for $10 \mathrm{~min}$. After PCR, $1 \mu \mathrm{l}$ of the product was mixed with $12 \mu \mathrm{l}$ of loading buffer containing formamide and Rox size standards. This mixture was denatured at $95^{\circ} \mathrm{C}$ for $2 \mathrm{~min}$ and cooled on ice before loading onto an ABI 310 Prism sequencer (Applied Biosystems, Foster City, CA). The results were analyzed using Genescan software (Applied Biosystems). Tumors were classified as MSI-H when $\geq 30 \%$ of the markers showed MSI in accordance with the recent recommendation of the National Cancer Institute Workshop. Tumors in which $<30 \%$ of the markers showed MSI were included in the MSI-L category. Alteration of even one microsatellite region led to definition of the patient as MSI-positive.

Determination of frameshift mutations of mononucleotide repeats in 11 cancer-related genes. DNA was extracted from tumor tissue from patients with MSI-H endometrial cancer using a Get Pure DNA kit (Dojindo Molecular Technologies). Somatic frameshift mutations in 11 cancer-related genes [hMSH3 (A8), hMSH6 (C8), TGF- $\beta R I I$ (A10), MBD4 (A10), BAX (G8), PTEN (A6), HDAC2 (A9), EPHB2 (A9), Caspase-5 (A10), TCF-4 (A9) and Axin2 (G7)] were determined using two gene-specific oligonucleotide primer pairs designed for PCR amplification of mononucleotide repeat regions. The oligonucleotide primers for sequencing of the 11 genes are shown in Table I. Each mononucleotide region was amplified by PCR using $0.5 \mu \mathrm{g}$ of template DNA, sense and antisense primers, and an AmpliTaq Gold PCR kit (Applied Biosystems). A 50- $\mu 1$ reaction mixture was prepared according to the manufacturer's instructions and PCR was started at $94^{\circ} \mathrm{C}$ for $3 \mathrm{~min}$; followed by 35 cycles of $94^{\circ} \mathrm{C}$ for $30 \mathrm{sec}, 64^{\circ} \mathrm{C}$ or $60^{\circ} \mathrm{C}$ for $30 \mathrm{sec}$, and $72^{\circ} \mathrm{C}$ for $1 \mathrm{~min}$; with a final extension step for $5 \mathrm{~min}$. The PCR products were purified using an UltraClean PCR Clean-up kit (Mobio Laboratories, Solana Beach, CA) and subjected to direct sequencing using purified products and the same sets of primers in a capillary automatic sequencer (ABI Prism 3100 Genetic Analyzer, Applied Biosystems). Sequence data were analyzed using the Basic Local Alignment Search Tool (BLAST) software located at the National Center for Biotechnology Information web site (http:/ www.ncbi.nlm.nih.gov). 

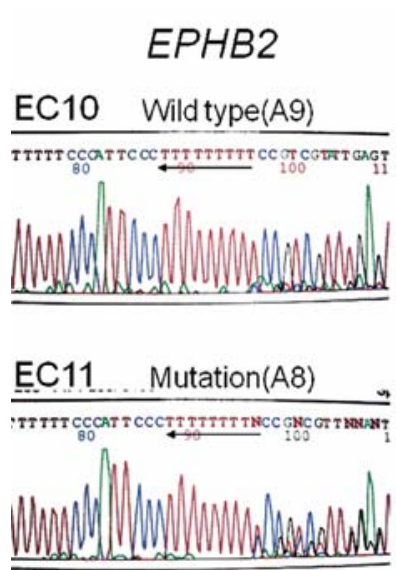

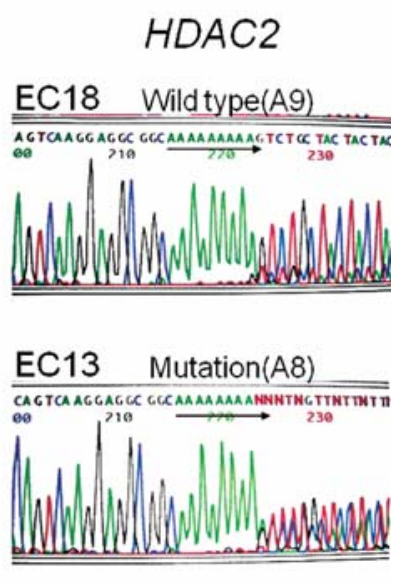

Figure 1. Analysis of mutations in MSI-H endometrial cancer. Frameshift mutations were observed in EPHB2 (A9) in case EC11 and HDAC2 (A9) in EC13.

Immunohistochemistry. Immunohistochemical staining was performed on $2-\mu \mathrm{m}$ sections of formalin-fixed, paraffinembedded tissues using standard procedures. Slides were cleaned in xylene and dehydrated in graded alcohols. Antigen retrieval was performed with 10 -min microwave treatment in $10 \mathrm{mM}$ citrate buffer ( $\mathrm{pH} 7.0)$. Endogenous peroxidase was blocked by dipping sections in $0.3 \% \mathrm{H}_{2} \mathrm{O}_{2}$ in methanol for 10 min. Slides were incubated with mouse monoclonal antibody to hMSH6 (clone44; BD Transduction Laboratories, San Jose, CA) (1:500) for $90 \mathrm{~min}$ at room temperature. Immunostaining was performed by the avidin-biotinperoxidase complex technique with an Elite ABC kit (Vector Laboratories, Burlingame, CA), using 3,3-diaminobenzidine as a chromogen and $\mathrm{H}_{2} \mathrm{O}_{2}$. Slides were counterstained with hematoxylin, dehydrated in graded alcohol, dried and coverslipped. The normal staining pattern for hMSH6 is nuclear, and nuclei in stromal cells were used as internal positive controls. For the purpose of the study, staining of tumor nuclei for hMSH6 was evaluated as positive (+) or negative (-).

Statistical analysis. The association of frameshift mutations in the mononucleotide repeat region of hMSH6 (C8) in MSI-H endometrial cancer specimens with mutations in the other 10 genes was analyzed using a Mann-Whitney test. The statistical association between mutations in hMSH6 (C8) and hMSH6 protein expression was analyzed using a Fisher's exact test.

\section{Results}

MSI was determined by PCR in 69 patients with endometrial cancer and 22 cases $(31.8 \%)$ were diagnosed as MSI-H. Mutations in mononucleotide repeats in 11 cancer-related genes [hMSH3 (A8), hMSH6 (C8), TGF- $\beta R I I$ (A10), MBD4 (A10), BAX (G8), PTEN (A6), HDAC2 (A9), EPHB2 (A9), Caspase-5 (A10), TCF-4 (A9) and Axin2 (G7)] were examined in the 22 cases of MSI-H endometrial cancer. Mutations in hMSH6 (C8) and TGF- $\beta R I I$ (A10) were found most frequently, each in $36.3 \%(8 / 22)$ of the cases. For the other genes, the percentages of cases with mutations were $9.1 \%(2 / 22)$ for

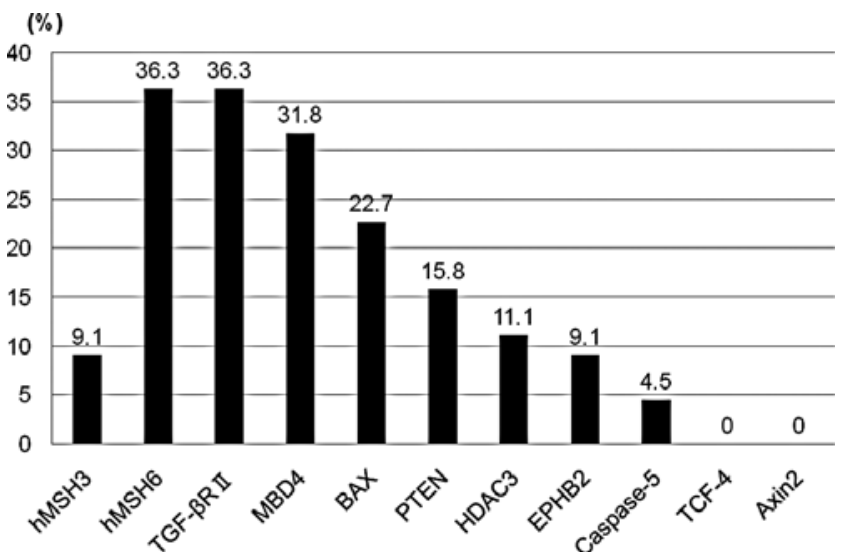

Figure 2. Frequency of mutations in mononucleotide repeats in cancerrelated genes in tissue samples from patients with MSI-H endometrial cancer. Mutations in $h M S H 6$ and TGF- $\beta R I I$ were found most frequently $(36.3 \%)$.
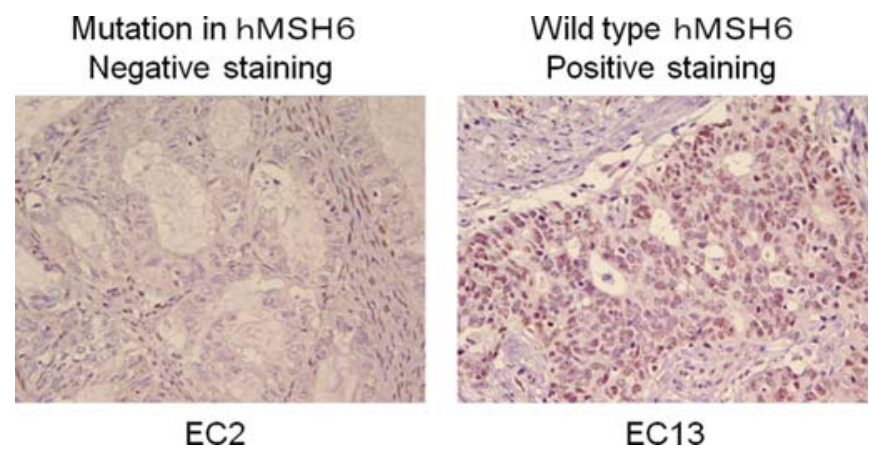

Figure 3. Immunohistochemical analysis of hMSH6 protein in endometrial cancer. Reduced expression of hMSH6 in tumor regions was found in case EC2, which had mutations in hMSH6. In contrast, hMSH6 showed clear staining in tumor cell nuclei in EC13, in which there were no mutations in hMSH6. In both specimens, normal nuclei surrounding the tumor are normally stained.

hMSH3 (A8), 31.8\% (6/18) for MBD4 (A10), $22.7 \%(5 / 22)$ for $B A X(\mathrm{G} 8), 15.8 \%$ (3/19) for PTEN (A6), $11.1 \%$ (2/18) for HDAC2 (A9), 9.1\% (2/22) for EPHB2 (A9), and $4.5 \%$ $(1 / 22)$ for Caspase-5 (A10). No mutation was found in the mononucleotide repeat regions of TCF-4 (A9) or Axin2 (G7) (Figs. 1 and 2, Table II).

Mutations were found most frequently in mononucleotide repeats in $h M S H 6(\mathrm{C} 8)$ among the 11 genes that were analyzed. Further analysis in patients with mutations in hMSH6 (C8) showed a statistically significant tendency for accumulation of mutations in mononucleotide repeats in one or more genes other than hMSH6 ( $\mathrm{p}=0.012$, Tables II and III). Furthermore, tumors with mutations in $h M S H 6$ showed significant negative immunostaining for hMSH6 protein $(\mathrm{p}=0.042$, Fig. 3, Table IV), indicating that mutations in hMSH6 correlated with reduced $h M S H 6$ protein expression.

\section{Discussion}

Microsatellite instability (MSI) is an indicator of genetic instability at the DNA level. MSI can be evaluated by detecting errors in replication of DNA regions referred to as 
Table II. Analysis of mutations in mononucleotide repeats in 11 cancer-related genes in tissue samples from patients with MSI-H endometrial cancer.

\begin{tabular}{|c|c|c|c|c|c|c|c|c|c|c|c|}
\hline Case & $\begin{array}{c}\text { hMSH3 } \\
\text { A8 }\end{array}$ & $\begin{array}{c}\text { hMSH6 } \\
\text { C8 }\end{array}$ & $\begin{array}{c}\text { TGF-ßRII } \\
\text { A10 }\end{array}$ & $\begin{array}{c}\text { MBD4 } \\
\text { A10 }\end{array}$ & $\begin{array}{c}\text { BAX } \\
\text { G8 }\end{array}$ & $\begin{array}{c}\text { PTEN } \\
\text { A6 }\end{array}$ & $\begin{array}{c}\text { HDAC2 } \\
\text { A9 }\end{array}$ & $\begin{array}{c}\text { EPHB2 } \\
\text { A9 }\end{array}$ & $\begin{array}{c}\text { Caspase-5 } \\
\text { A10 }\end{array}$ & $\begin{array}{c}\text { TCF-4 } \\
\text { A9 }\end{array}$ & $\begin{array}{c}\text { Axin2 } \\
\text { G7 }\end{array}$ \\
\hline EC1 & - & + & - & + & - & ND & ND & - & - & - & - \\
\hline $\mathrm{EC} 2$ & - & + & + & + & - & ND & - & - & - & - & - \\
\hline EC3 & - & + & - & - & - & + & - & - & - & - & - \\
\hline EC4 & - & + & + & ND & - & - & - & + & - & - & - \\
\hline EC5 & - & + & + & ND & + & - & - & - & - & - & - \\
\hline EC6 & - & + & + & + & - & + & - & - & - & - & - \\
\hline EC7 & + & + & + & - & - & + & - & + & - & - & - \\
\hline EC8 & - & + & + & - & + & - & - & - & - & - & - \\
\hline EC9 & - & - & - & - & + & ND & + & - & - & - & - \\
\hline EC10 & - & - & + & - & - & - & - & - & - & - & - \\
\hline EC11 & - & - & + & - & - & - & ND & - & - & - & - \\
\hline EC12 & - & - & - & + & & - & ND & - & - & - & - \\
\hline EC13 & - & - & - & - & - & - & + & - & - & - & - \\
\hline EC14 & - & - & - & - & - & - & - & - & - & - & - \\
\hline EC15 & - & - & - & - & - & - & - & - & + & - & - \\
\hline EC16 & - & - & - & - & - & - & - & - & - & - & - \\
\hline EC17 & + & - & - & - & - & - & - & - & - & - & - \\
\hline EC18 & - & - & - & ND & - & - & - & - & - & - & - \\
\hline EC19 & - & - & - & - & - & - & - & - & - & - & - \\
\hline EC20 & - & - & - & ND & & - & ND & - & - & - & - \\
\hline $\mathrm{EC} 21$ & - & - & - & + & + & - & - & - & - & - & - \\
\hline $\mathrm{EC} 22$ & - & - & - & + & + & - & - & - & - & - & - \\
\hline
\end{tabular}

+ , mutated; -, wild-type and ND, not done.

Table III. Association of mutations in hMSH6 in MSI-H endometrial cancer with mutations in 10 other cancer-related genes ( $\mathrm{p}=0.012$, Mann-Whitney test).

\begin{tabular}{llllll}
\hline & \multicolumn{4}{c}{$\begin{array}{c}\text { No. of mutations in 10 genes } \\
\text { (other than hMSH6) }\end{array}$} \\
\cline { 2 - 6 } & 0 & 1 & 2 & 3 & 4 \\
\hline Mutation in hMSH6 & 0 & 2 & 4 & 0 & 2 \\
No mutation in hMSH6 & 4 & 7 & 2 & 1 & 0 \\
\hline
\end{tabular}

Statistical analysis was performed by Mann-Whitney test $(\mathrm{p}=0.012)$.

microsatellites, which consist of a sequence of repeating units of 1 or 2 base pairs. HNPCC is a familial tumor that is very frequently MSI positive and is probably caused by germline mutations in DNA mismatch repair (MMR) genes that cause abnormalities in the MMR system. This results in frequent replication errors of various target genes followed by malignant transformation. In MSI-positive colorectal cancer, mutations of $T G F-\beta R I I$ and $B A X$ tumor suppressor genes are frequently found and these genes are considered to be MSI target genes. TGF- $\beta R I I$ and $B A X$ include mononucleotide repeats susceptible to MSI and are likely to be mutated in MSI-positive tumors; therefore, these mutations are suspected to be involved in malignant transformation of cells.

Approximately 30\% of MSI-positive endometrial cancer is defined as MSI-H, but a responsible MSI-target gene has not been identified in endometrial cancer. In this study, we analyzed MSI in 69 patients with endometrial cancer and $22(31.8 \%)$ were diagnosed as MSI-H. This result is similar to those in previous studies. Mutations in mononucleotide repeats in 11 cancer-related genes were analyzed in the 22 cases of MSI-H endometrial cancer. Mutations in hMSH6 (C8) and TGF- $\beta R I I$ (A10) were found most frequently (36.3\%), whereas no mutation was found in TCF-4 (A9) or Axin2 (G7), which are components of the Wnt-signaling pathway. Mutations in PTEN (A6), which has a high frequency of mutations in MSI-positive endometrial cancer, were found in $15.8 \%$ of the 22 cases.

TGF- $\beta$ inhibits growth of epithelial cells and TGF-ßRII transmits growth inhibitory signals; therefore, a loss of the function of these proteins may lead to malignant transformation of cells. In a previous study, mutations of TGF- $\beta R I I$ (A10) were found in $90 \%$ of MSI-positive colorectal cancer, whereas no mutation was found in MSI-negative colorectal cancer, which suggests that $T G F-\beta R I I$ plays an important role in malignant transformation as an MSI-target gene (28). Similarly, mutations of $B A X(\mathrm{G} 8)$, which is involved in apoptosis, have been found in $45 \%$ of cases of MSI-positive colorectal cancer and $B A X$ is thought to be related to malignant 
Table IV. Association of mutations in hMSH6 in MSI-H endometrial cancer with reduced hMSH6 protein expression.

\begin{tabular}{lccc}
\hline & Positive & Negative & Total \\
\hline Mutation in hMSH6 & 2 & 6 & 8 \\
Wild-type in hMSH6 & 11 & 1 & 12 \\
Total & 13 & 7 & 20 \\
\hline
\end{tabular}

Statistical analysis was performed by Fisher's exact test ( $\mathrm{p}=0.042$ ).

transformation in this cancer as an MSI target gene (29). The mutation rates of $T G F-\beta R I I$ (A10) and $B A X$ (G8) in MSI-H endometrial cancer have been shown to be 12 and $33 \%$, respectively (29), whereas we found rates of 36.3 and $22.7 \%$, respectively, with these rates being the highest and third highest among the 11 genes analyzed. However, both rates are much lower than those found in MSI-positive colorectal cancer. Mutations in TCF-4 (A9), a component of the Wntsignaling pathway, were not found in our specimens, but occur at a frequency of 39\% in MSI-positive colorectal cancer (29). This suggests that the frequency of mutations in mononucleotide repeats differs substantially between colorectal and endometrial cancers, and that MSI target genes and the mechanism of malignant transformation may also differ between these cancers.

Mutations in PTEN are found in about $60 \%$ of cases of MSI-positive endometrial cancer and about $30 \%$ of cases of MSI-negative endometrial cancer $(30,31)$. The significantly higher rate in MSI-positive endometrial cancer suggests an association with MSI. Mutations in mononucleotide A repeats in exons 7 and 8 of PTEN are found in $27 \%$ of cases of MSI-positive endometrial cancer, which suggests that PTEN is an MSI-target gene (31), but PTEN mutation patterns vary and another study found mutations in the mononucleotide $\mathrm{A}$ repeats in only $3 \%$ of cases of endometrial cancers with microsatellite instability (32). The results of our study showed a $15.8 \%$ mutation rate for PTEN (A6), which was lower than those for $h M S H 6$ and TGF- $\beta R I I$.

The function of hMSH6 is to detect deletion or insertion of a base pair in a mononucleotide repeat sequence and to initiate repair by forming a complex with hMSH2, hPMS2 and hMLH1. Reduced expression of hMSH6 due to mutation of hMSH6 damages MMR function and induces MSI, which may result in malignant transformation of cells. Hendriks et al investigated families with germline mutations in $h M S H 6$ and showed that carriers of these mutations had a significantly higher risk of endometrial cancer than carriers of an $\mathrm{hMSHI}$ or hMSH2 mutation (33). Furthermore, $69 \%$ of cases of endometrial cancer among $h M S H 6$ mutation carriers were MSI-H and immunohistochemistry showed that $97.5 \%$ were negative for hMSH6, indicating reduced expression of $h M S H 6$ (33). These results suggest that reduced expression of $h M S H 6$ caused by germline mutation induces MSI and is associated with development of hereditary endometrial cancer. Somatic mutations in hMSH6 in MSI-positive sporadic endometrial cancer patients have been shown in several studies, but it is unclear if these mutations have an important role $(34,35)$.
Goodfellow et al found somatic mutations in $h M S H 6$ in 16 of 60 patients $(26.6 \%)$ with MSI-H endometrial cancer and frameshift mutations in $\mathrm{C} 8$ in 12 of 16 patients with a somatic mutation, but no somatic mutation in hMSH6 in MSInegative patients. In the current study, frameshift mutations in $h M S H 6$ (C8) were found in $36.3 \%$ of patients, higher than the rate in Goodfellow et al, and immunohistochemical analysis showed that mutation of $h M S H 6$ correlated with reduced protein expression. These results suggest that mutation in $h M S H 6$ plays an important role in development of MSI-H sporadic endometrial cancer, similarly to hereditary endometrial cancer.

The current results also showed that patients with mutations in hMSH6 (C8) had a tendency for accumulation of mutations in mononucleotide repeats in other genes. This tendency was found only in patients with mutations in hMSH6 (C8). In MSI-positive colorectal cancer, Ikeda et al found that mutations in E2F4 (CAG13), which codes for a transcriptional activator, were often associated with mutations in $h M S H 3$ (A8), an MMR gene that repairs dinucleotide and trinucleotide repeats, and proposed an interesting hypothesis in which mutations in trinucleotide repeats in E2F4 are induced by mutations in $h M S H 3$, with a subsequent reduction in expression (36). A cascade of malignant transformation with a similar mechanism to this hypothesis may also occur in MSI-H endometrial cancer, with mutations in hMSH6, a repair gene for mononucleotide repeats, inducing mutations in tumor suppressor genes that include mononucleotide repeats, such as $T G F-\beta R I I$ (A10), BAX (G8) and $\beta$ (A6).

Collectively, the results of this study suggest the possibility of a novel cascade in endometrial cancer, in which MSI caused by reduced expression of $h M L H 1$ due to aberrant hypermethylation (epigenetic change) leads to mutation of $h M S H 6$ (C8), an MSI target gene, and reduced expression of hMSH6 subsequently increases gene instability and leads to accumulation of mutations in other cancer-related genes (genetic change), resulting in malignant transformation. This is the first study to show that $h M S H 6$ (C8) has an important role in the mechanism of malignant transformation in MSI-H sporadic endometrial cancer as a target gene, and further studies on the proposed cascade may provide new drugs and preventive approaches for endometrial cancer.

\section{Acknowledgements}

This study was supported by the Japan Society for the Promotion of Science (JSPS) through a Grant-in-Aid for Scientific Research (KAKENHI); a Grant-in-Aid for Young Scientists (B) (21791573); Akaeda Medical Research Foundation; The Public Trust Fund for Clinical Cancer Research; and the Keio University Medical Science Fund through a Research Grant for Life Sciences and Medicine.

\section{References}

1. Ionov Y, Peinado MA, Malkhosyan S, Shibata D and Perucho M: Ubiquitous somatic mutations in simple repeated sequences reveal a new mechanism for colonic carcinogenesis. Nature 363: 558-561, 1993.

2. Thibodeau SN, Bren G and Schaid D: Microsatellite instability in cancer of the proximal colon. Science 260: 816-819, 1993. 
3. Aaltonen LA, Peltomäki P, Leach FS, Sistonen P, Pylkkänen L, Mecklin JP, Järvinen H, Powell SM, Jen J, Hamilton SR, Petersen GM, Kinzler KW, Vogelstein B and Chapelle A: Clues to the pathogenesis of familial colorectal cancer. Science 260: $812-816,1993$

4. Papadopoulos N, Nicolaides NC, Wei YF, Ruben SM, Carter KC, Rosen CA, Haseltine WA, Fleischmann RD, Fraser CM and Adams MD: Mutation of a mutL homolog in hereditary colon cancer. Science 263: 1625-1629, 1994.

5. Bronner CE, Baker SM, Morrison PT, Warren G, Smith LG, Lescoe MK, Kane M, Earabino C, Lipford J, Lindblom A, Tannergard P, Bollag RJ, Godwin AR, Ward DC, Nordenskj M, Fishel R, Kolodner R and Liskay LM: Mutation in the DNA mismatch repair gene homologue hMLH1 is associated with hereditary non-polyposis colon cancer. Nature 368: 258-261, 1994

6. Fishel R, Lescoe MK, Rao MR, Copeland NG, Jenkins NA, Garber J, Kane M and Kolodner R: The human mutator gene homolog MSH2 and its association with hereditary nonpolyposis colon cancer. Cell 75: 1027-1038, 1993.

7. Leach FS, Nicolaides NC, Papadopoulos N, Liu B, Jen J Parsons R, Peltomäki P, Sistonen P, Aaltonen LA and NyströmLahti M: Mutations of a mutS homolog in hereditary nonpolyposis colorectal cancer. Cell 75: 1215-1225, 1993.

8. Wu Y, Berends MJ, Sijmons RH, Mensink RG, Verlind E, Kooi KA, van der Sluis T, Kempinga C, van der Zee AG, Hollema H, Buys CH, Kleibeuker JH and Hofstra RM: A role for MLH3 in hereditary nonpolyposis colorectal cancer. Nat Genet 29: 137-138, 2001 .

9. Papadopoulos N, Nicolaides NC, Liu B, Parsons R, Lengauer C, Palombo F, D'Arrigo A, Markowitz S, Willson JK and Kinzler KW: Mutations of GTBP in genetically unstable cells. Science 268: 1915-1917, 1995

10. Drummond JT, Li GM, Longley MJ and Modrich P: Isolation of an hMSH2-p160 heterodimer that restores DNA mismatch repair to tumor cells. Science 268: 1909-1912, 1995.

11. Nicolaides NC, Papadopoulos N, Liu B, Wei YF, Carter KC Ruben SM, Rosen CA, Haseltine WA, Fleischmann RD and Fraser CM: Mutations of two PMS homologues in hereditary nonpolyposis colon cancer. Nature 371: 75-80, 1994.

12. Kane MF, Loda M, Gaida GM, Lipman J, Mishra R, Goldman H, Jessup JM and Kolodner R: Methylation of the hMLH1 promoter correlates with lack of expression of hMLH1 in sporadic colon tumors and mismatch repair-defective human tumor cell lines. Cancer Res 57: 808-811, 1997.

13. Herman JG, Umar A, Polyak K, Graff JR, Ahuja N, Issa JP, Markowitz S, Willson JK, Hamilton SR, Kinzler KW, Kane MF, Kolodner RD, Vogelstein B, Kunkel TA and Baylin SB: Incidence and functional consequences of hMLH1 promoter hypermethylation in colorectal carcinoma. Proc Natl Acad Sci USA 95: 68706875,1998

14. Hirasawa A, Aoki D, Inoue J, Imoto I, Susumu N, Sugano K, Nozawa $S$ and Inazawa $J$ : Unfavorable prognostic factors associated with high frequency of microsatellite instability and comparative genomic hybridization analysis in endometrial cancer. Clin Cancer Res 9: 5675-5682, 2003.

15. Mutch DG, Powell MA, Mallon MA and Goodfellow PJ: RAS/RAF mutation and defective DNA mismatch repair in endometrial cancers. Am J Obstet Gynecol 190: 935-942, 2004.

16. Simpkins SB, Bocker T, Swisher EM, Mutch DG, Gersell DJ, Kovatich AJ, Palazzo JP, Fishel R and Goodfellow P: MLH1 promoter methylation and gene slicing is the primary cause of microsatellite instability in sporadic endometrial cancers. Hum Mol Genet 8: 661-666, 1999.

17. Markowitz S, Wang J, Myeroff L, Parsons R, Sun L, Lutterbaugh J, Fan RS, Zborowska E, Kinzler KW, Vogelstein B, Brattain M and Wilson JKV: Inactivation of the type II TGF-beta receptor in colon cancer cells with microsatellite instability. Science 268: 1336-1338, 1995.

18. Kong D, Suzuki A, Zou TT, Sakurada A, Kemp LW, Wakatsuki S, Yokoyama T, Yamakawa H, Furukawa T, Sato M Ohuchi N, Sato S, Yin J, Wang S, Abraham JM, Souza RF, Smolinski KN, Meltzer SJ and Horii A: PTEN1 is frequently mutated in primary endometrial carcinomas. Nat Genet 17 : 143-144, 1997.

19. Ouyang H, Furukawa T, Abe T, Kato Y and Horii A: The BAX gene, the promoter of apoptosis, is mutated in genetically unstable cancers of the colorectum, stomach, and endometrium. Clin Cancer Res 4: 1071-1074, 1998
20. Schwartz S Jr, Yamamoto H, Navarro M, Maestro M, Reventós J and Perucho M: Frameshift mutations at mononucleotide repeats in caspase-5 and other target genes in endometrial and gastrointestinal cancer of the microsatellite mutator phenotype. Cancer Res 59: 2995-3002, 1999.

21. Duval A, Gayet J, Zhou XP, Iacopetta B, Thomas G and Hamelin R: Frequent frameshift mutations of the TCF-4 gene in colorectal cancers with microsatellite instability. Cancer Res 59: 4213-4215, 1999.

22. Alazzouzi H, Davalos V, Kokko A, Domingo E, Woerner SM, Wilson AJ, Konrad L, Laiho P, Espín E, Armengol M, Imai K, Yamamoto H, Mariadason JM, Gebert JF, Aaltonen LA Schwartz S Jr and Arango D: Mechanisms of inactivation of the receptor tyrosine kinase EPHB2 in colorectal tumors. Cancer Res 65: 10170-10173, 2005.

23. Liu W, Dong X, Mai M, Seelan RS, Taniguchi K, Krishnadath KK, Halling KC, Cunningham JM, Boardman LA, Qian C, Christensen E, Schmidt SS, Roche PC, Smith DI and Thibodeau SN: Mutations in AXIN2 cause colorectal cancer with defective mismatch repair by activating beta-catenin/TCF signalling. Nat Genet 26: 146-147, 2000.

24. Ropero S, Fraga MF, Ballestar E, Hamelin R, Yamamoto H, Boix-Chornet M, Caballero R, Alaminos M, Setien F, Paz MF, Herranz M, Palacios J, Arango D, Orntoft TF, Aaltonen LA, Schwartz S Jr and Esteller M: A truncating mutation of HDAC2 in human cancers confers resistance to histone deacetylase inhibition. Nat Genet 38: 566-569, 2006.

25. Malkhosyan S, Rampino N, Yamamoto $H$ and Perucho $M$ : Frameshift mutator mutations. Nature 382: 499-500, 1996.

26. Yamamoto H, Sawai $\mathrm{H}$ and Perucho $\mathrm{M}$ : Frameshift somatic mutations in gastrointestinal cancer of the microsatellite mutator phenotype. Cancer Res 57: 4420-4426, 1997.

27. Bader S, Walker M, Hendrich B, Bird A, Bird C, Hooper M and Wyllie A: Somatic frameshift mutations in the MBD4 gene of sporadic colon cancers with mismatch repair deficiency. Oncogene 18: 8044-8047, 1999.

28. Parsons R, Myeroff LL, Liu B, Willson JK, Markowitz SD, Kinzler KW and Vogelstein B: Microsatellite instability and mutations of the transforming growth factor beta type II receptor gene in colorectal cancer. Cancer Res 55: 5548-5550, 1995.

29. Duval A and Hamelin R: Mutations at coding repeat sequences in mismatch repair-deficient human cancers: toward a new concept of target genes for instability. Cancer Res 62: 2447-2454, 2002.

30. Bilbao C, Rodríguez G, Ramírez R, Falcón O, León L, Chirino R, Rivero JF, Falcón O Jr, Díaz-Chico BN, Díaz-Chico JC and Perucho M: The relationship between microsatellite instability and PTEN gene mutations in endometrial cancer. Int J Cancer 119: 563-570, 2006.

31. Bussaglia E, del Rio E, Matias-Guiu X and Prat J: PTEN mutations in endometrial carcinomas: a molecular and clinopathologic analysis of 38 cases. Hum Pathol 31: 312-317, 2000.

32. Cohn DE, Basil JB, Venegoni AR, Mutch DG, Rader JS, Herzog TJ, Gersell DJ and Goodfellow PJ: Absence of PTEN repeat tract mutation in endometrial cancers with microsatellite instability. Gynecol Oncol 79: 101-106, 2000.

33. Hendriks YM, Wagner A, Morreau H, Menko F, Stormorken A, Quehenberger F, Sandkuijl L, Møller P, Genuardi M, Van Houwelingen H, Tops C, Van Puijenbroek M, Verkuijlen P, Kenter G, Van Mil A, Meijers-Heijboer H, Tan GB, Breuning MH, Fodde R, Wijnen JT, Bröcker-Vriends AH and Vasen $\mathrm{H}$ : Cancer risk in hereditary nonpolyposis colorectal cancer due to MSH6 mutations: impact on counseling and surveillance. Gastroenterology 127: 17-25, 2004.

34. Goodfellow PJ, Buttin BM, Herzog TJ, Rader JS, Gibb RK, Swisher E, Look K, Walls KC, Fan MY and Mutch DG: Prevalence of defencive DNA mismatch repair and MSH6 mutation in an unselected series of endometrial cancers. Proc Natl Acad Sci USA 100: 5908-5913, 2003.

35. Duval A, Iacopetta B, Ranzani GN, Lothe RA, Thomas G and Hamelin R: Variable mutation frequencies in coding repeats of TCF-4 and other target genes in colon, gastric and endometrial carcinoma showing microsatellite instability. Oncogene 18: 6806-6809, 1999.

36. Ikeda M, Orimo H, Moriyama H, Nakajima E, Matsubara N, Mibu R, Tanaka N, Shimada T, Kimura A and Shimizu K: Close correlation between mutations of E2F4 and hMSH3 genes in colorectal cancers with microsatellite instability. Cancer Res 58: 594-598, 1998. 